DOI: $\underline{10.35619 / \text { iiu.v1i13.370 }}$

Козак Людмила

доктор педагогічних наук, доцент, професор кафедри дошкільної освіти Київського університету імені Бориса Грінченка, м. Київ, Україна, ORCID: 0000-0002-4528-1905 e-mail:l.kozak@kubg.edu.ua

\title{
ТЕХНОЛОГІЧНІ ЗАСАДИ ПІДГОТОВКИ МАЙБУТНІХ МАГІСТРІВ 3 ДОШКІЛЬНОЇ ОСВІТИ ДО ІННОВАЦІЙНОЇ ПРОФЕСІЙНОЇ ДІЯЛЬНОСТІ
}

Анотація. У статті обгрунтовано технологічні засади підготовки майбутніх магістрів 3 дошкільної освіти до інноваційної професійної діяльності; подано авторське тлумачення понять «інноваційна професійна діяльність магістра 3 дошкільної освіти», «готовність магістра до інноваційної професійної діяльності»; представлено розроблену технологію підготовки їх до інноваційної професійної діяльності, яка містить концептуальний, змістово-процесуальний, оцінно-результативний компоненти. Концептуальний компонент розкриває провідну ідею, мету, завдання, підходи, принципи підготовки майбутніх магістрів 3 дошкільної освіти до інноваційної професійної діяльності. Змістово-процесуальний компонент охоплює етапи підготовки майбутніх магістрів до інноваційної професійної діяльності. Оцінно-результативний компонент відображає процедуру оцінювання рівня готовності майбутніх магістрів 3 дошкільної освіти до інноваційної професійної діяльності та результат такої підготовки. Формування готовності майбутніх магістрів до інноваційної професійної діяльності відбувається у процесі оволодіння інноваційною складовою змісту навчальних дисциплін та виробничої практики, використання технологій проблемного, евристичного, проєктного, контекстного, інтерактивного, змішаного навчання, цифрових сервісів і ресурсів, сучасних форм організації освітнього процесу в закладі вищої освіти.

Ключові слова: інноваційна діяльність, магістр $з$ дошкільної освіти, готовність до інноваційної професійної діяльності, інноваційна педагогічна технологія, технологія підготовки до інноваційної професійної діяльності.

Постановка проблеми. У Національній стратегії розвитку освіти в Україні на період до 2021 року зазначено, що одним із ключових напрямів державної освітньої політики має стати розвиток наукової та інноваційної діяльності, підвищення якості освіти на інноваційній основі, 


\section{Інноватика у вихованні. Випуск 13.Том 1. 2021.}

переорієнтація змісту освіти на цілі сталого розвитку (Національна стратегія розвитку освіти в Україні на період до 2021 року, 2013).

Інноваційні процеси в системі вітчизняної освіти, і дошкільної зокрема, потребують педагога нового типу і висувають значні вимоги до його професійної підготовки. Сьогодні закладам дошкільної освіти потрібні фахівці, здатні на високому рівні надавати освітні послуги, вносити у власну діяльність прогресивні ідеї, запроваджувати нововведення, вміло поєднувати традиційне 3 новим, забезпечувати цілісний розвиток особистості дитини. На важливість означеної проблеми вказано у Концепції розвитку педагогічної освіти (2018). Як зазначено в документі, завданням другого (магістерського) рівня вищої педагогічної освіти $є$ підготовка висококваліфікованих педагогічних працівників для усіх складників освіти, які здатні розв'язувати складні задачі та проблеми навчання, виховання й розвитку, що передбачає проведення досліджень та/або здійснення інновацій, характеризується невизначеністю умов і вимог. Вони мають бути здатними брати участь у створенні та впровадженні нового змісту освіти та новітніх методик (технологій) навчання, поєднувати власну педагогічну діяльність на високому професійному рівні 3 поширенням кращої практики, експертною діяльністю та наставництвом на основі власного педагогічного досвіду (Концепція розвитку педагогічної освіти, 2018).

У цьому контексті актуальності набуває підготовка майбутніх магістрів 3 дошкільної освіти до інноваційної професійної діяльності, об’єктом вивчення та діяльності яких $є$ організація дошкільної освіти, освітня і психолого-педагогічна інноватика, організація і забезпечення освітнього процесу в закладах вищої освіти 3 підготовки фахівців для системи дошкільної освіти (Стандарт вищої освіти. Другий (магістерський) рівень вищої освіти, 2020).

Аналіз останніх досліджень 3 проблеми. У вітчизняній педагогіці досліджуються різні аспекти підготовки вчителів до інноваційної діяльності, зокрема, формування готовності їх до інноваційної педагогічної діяльності у процесі професійної підготовки (І. В. Гавриш, О. А. Гончарова, Т. М. Демиденко, Н. І. Клокар, О. Г. Козлова, В. М. Малихіна, О. І. Огієнко, Л. О. Пертиченко, О. І. Шапран, Л. С. Шевченко та інші); підготовка майбутніх вихователів дошкільних закладів до інноваційної педагогічної діяльності (I. М. Дичківська); теоретико-методологічні засади підготовки майбутніх викладачів дошкільної педагогіки і психології до інноваційної професійної діяльності (Л. В. Козак); упровадження інноваційних технологій у підготовку педагогічних кадрів (I. М. Богданова, О. Н. Пєхота, С. О. Сисоєва та інші).

Інноваційна діяльність педагога розглядається дослідниками в таких аспектах: як розроблення, освоєння й використання нововведень (I. В. Гавриш); як вищий щабель педагогічної творчості (О. Г. Козлова); як експериментальна і пошукова діяльність педагогічних працівників з метою розроблення експерименту, апробації, впровадження i застосування 


\section{Інноватика у вихованні. Випуск 13.Том 1. 2021.}

педагогічних інновацій (В. М. Малихіна); як складне, інтегральне утворення, сукупність різних за цілями та характером видів робіт, що відповідають основним етапам розвитку інноваційних процесів та спрямовані на внесення педагогом позитивних змін до власної системи роботи (О. І. Шапран); як комплексна багатофункціональна творча діяльність, спрямована на організацію суб'єкт-суб'єктної взаємодії в системі «викладач-студент», яка забезпечує розвиток інноваційної особистості студента, його готовність до застосування, розроблення та упровадження педагогічних інновацій у систему дошкільної освіти (Козак, 2015, с.15).

Інноваційна педагогічна діяльність у дошкільній освіті грунтується на принципах особистісного підходу, носить творчий характер, організовується у формі дослідно-експериментальної роботи, має стійку мотивованість на пошук нового в цільових, змістових і процесуальних характеристиках навчально-виховного процесу дошкільного закладу (Дичківська, 2017, с.175-176).

Аналіз наукових джерел з проблеми дослідження дозволяє розглядати інноваційну професійну діяльність магістра 3 дошкільної освіти як комплексну багатофункціональну творчу діяльність, спрямовану на інноваційний розвиток і підвищення якості дошкільної освіти шляхом застосування, розроблення та упровадження педагогічних інновацій в систему дошкільної освіти або в процес навчання дошкільних педагогів у закладах вищої освіти.

Мета статті - обгрунтувати технологічні засади підготовки майбутніх магістрів з дошкільної освіти до інноваційної професійної діяльності.

Виклад основного матеріалу дослідження. Інновації в освіті закономірно вимагають відповідного оновлення педагогічної технології, яка грунтується на досягненнях науки і функціонує як система способів, принципів і регуляторів, що застосовуються у навчанні. С. О. Сисоєва розглядає педагогічну технологію як засіб реалізації мети, яку ставить перед собою педагог, i яка завжди формується та розробляється визначеним концептуальним підходом і відображає систему педагогічних поглядів (Сисоєва, 2003. с. 449-564). Ми поділяємо думку, що у загальному розумінні технологія - це розробка ідеї. Тому поняття технології освітнього процесу розглядається як моделювання його змісту, форм i методів відповідно до поставленої мети.

Нині в педагогічній літературі широко застосовується термін «інноваційна педагогічна технологія». Ми дотримуємося визначення «інноваційна педагогічна технологія», яке подає О. І. Шапран. Дослідниця тлумачить інноваційну педагогічну технологію як таку, що поєднує науково-обгрунтовану систему дій, операцій та процедур, які забезпечують цілеспрямоване й поопераційне впровадження різних видів педагогічних нововведень, котрі викликають позитивні зміни в традиційному педагогічному процесі, модернізують і трансформують його (Шапран, c. 43). 


\section{Інноватика у вихованні. Випуск 13.Том 1. 2021.}

У нашому дослідженні технологія підготовки майбутніх магістрів 3 дошкільної освіти до інноваційної професійної діяльності розглядається як комплексна система роботи викладача, що включає планування i організацію інноваційного освітнього процесу відповідно до критеріїв технологічності, метою якої $\epsilon$ розвиток інноваційної особистості магістранта, формування його готовності до застосування, розроблення та упровадження інновацій в системі дошкільної освіти або в процесі професійної підготовки дошкільних педагогів.

Технологію підготовки майбутніх магістрів 3 дошкільної освіти до інноваційної професійної діяльності розглядаємо на предметнометодичному рівні та виокремлюємо в ній концептуальний, змістовопроцесуальний та оцінно-результативний компоненти.

У контексті вищезазначеного обгрунтуємо складові технології підготовки майбутніх магістрів дошкільної освіти до інноваційної професійної діяльності.

Провідна концептуальна ідея підготовки майбутніх магістрів 3 дошкільної освіти до інноваційної професійної діяльності грунтується на положенні про те, що така підготовка має здійснюватися на основі органічної єдності загального, особливого та індивідуального. Як загальне - вона $\epsilon$ органічною складовою загально-педагогічної підготовки майбутніх магістрів і визначається єдністю вимог до якості їх підготовки до інноваційної професійної діяльності на всіх її етапах; як особливе - має свою специфіку, зумовлену властивостями технології підготовки магістрантів до інноваційної професійної діяльності; як індивідуальне відображає залежність результатів підготовки від особистісних якостей майбутніх магістрів 3 дошкільної освіти.

Ми виходимо $з$ того, що підготовка майбутніх магістрів 3 дошкільної освіти до інноваційної професійної діяльності має бути цілісною, відображати у своєму логічному розгортанні iї зміст і структуру та забезпечувати формування у магістрів усіх компонентів готовності до інноваційної професійної діяльності.

Готовність магістра 3 дошкільної освіти до інноваційної професійної діяльності розглядаємо як результат його підготовки у закладі вищої освіти, який відображає систему мотивів, знань, умінь, навичок, професійно-особистісних якостей, що забезпечують успішність інноваційної професійної діяльності магістра, результатом якої $\epsilon$ нововведення, які позитивно змінюють систему освіти, визначають іiі якість і розвиток.

Відповідно до зазначених положень, концептуальною метою технології $є$ розвиток інноваційної особистості магістра 3 дошкільної освіти 3 високим рівнем сформованої готовності до інноваційної професійної діяльності.

Нами виділено такі основні завдання технології:

збагачення інноваційною складовою змісту навчальних дисциплін, виробничої практики, тематики магістерських досліджень; 


\section{Інноватика у вихованні. Випуск 13.Том 1. 2021.}

забезпечення інтеграції теоретичного i практичного навчання, науково-дослідної та експериментально-впроваджувальної діяльності магістрантів;

відбір форм, методів і технологій навчання, що забезпечують активізацію креативності магістрантів у процесі навчання, посилюють особистісну орієнтацію та професійну спрямованість на інноваційну діяльність;

формування готовності магістрантів до інноваційної професійної діяльності, що охоплює взаємопов'язані компетентності щодо створення, впровадження та поширення педагогічних інновацій у дошкільній освіті;

розвиток інноваційного мислення та інноваційного стилю діяльності.

Підготовка майбутніх магістрів дошкільної освіти до інноваційної професійної діяльності розглядається як цілісна система, що будується на системному, компетентнісному, особистісно-орієнтованому, дослідницькому, діяльнісно-рефлексивному, індивідуально-творчому, інтегративному підходах.

Серед принципів підготовки майбутніх магістрів 3 дошкільної освіти до інноваційної професійної діяльності ми виділяємо як загальнопедагогічні принципи, так і специфічні, що відображають особливості інноваційної підготовки, а саме: «інноваційної» інформації, інтеграції, інформатизації, відповідності змісту навчання структурі інноваційної професійної діяльності, пріоритетності дослідницької, творчої проєктної діяльності, партнерства і співробітництва, єдності загального, особливого та індивідуального в навчанні.

Реалізація концептуальних положень технології дає можливість підготувати конкурентоспроможного на ринку праці магістра з дошкільної освіти, здатного до інноваційної професійної діяльності.

Змістово-процесуальний компонент технології розкриває особливості змісту підготовки майбутніх магістрів 3 дошкільної освіти до інноваційної професійної діяльності, форми організації освітнього процесу, методи, засоби і технологій навчання, які утворюють цілісний інноваційний освітній процес.

Проведений аналіз визначених стандартом вищої освіти загальних та фахових компетентностей магістрів спеціальності «Дошкільна освіта» дозволив нам виділити ті, які відображають зміст інноваційної професійної діяльності, а саме: знання механізмів реалізації інноваційних ідей в дошкільній освіті та забезпечення їі якості; вміння генерувати нові ідеї для роботи з дітьми різного віку, використовувати оригінальні рішення, передбачати їх ефективність і результативність; вміння організовувати освітній процес у закладах дошкільної освіти 3 використанням сучасних засобів, методів, прийомів і технологій; вміння залучати до інноваційної діяльності однодумців, активізувати колектив професіоналів до продукування й обговорення креативних ідей i їх успішного втілення; володіння способами розробки освітніх проєктів та їх упровадження в практику роботи зі студентами й дітьми дошкільного віку; вміння 


\section{Інноватика у вихованні. Випуск 13.Том 1. 2021.}

зацікавлювати й переконувати учасників освітнього процесу в необхідності брати участь у розробці та впровадженні інноваційних проєктів та інші (Стандарт вищої освіти. Другий (магістерський) рівень вищої освіти, 2020).

Ми виходимо 3 того, що сучасний зміст підготовки майбутніх магістрів 3 дошкільної освіти має бути спрямований на формування компонентів готовності до інноваційної професійної діяльності і містити такі складові елементи: досвід ціннісного ставлення до інноваційної професійної діяльності (ціннісно-мотиваційний компонент); систему наукових знань про інновації в дошкільній та вищій педагогічній освіті, сутність, структуру та технологію інноваційної професійної діяльності (інформаційно-когнітивний компонент); систему умінь щодо оволодіння відбором педагогічних інновацій, їх оцінювання і застосування в освітній практиці; досвід творчої діяльності щодо створення і реалізації авторських інноваційних проєктів в освітньому середовищі закладу дошкільної та/або вищої педагогічної освіти (діяльнісно-творчий компонент); досвід оволодіння способами самопізнання, саморегуляції та самореалізації, формування життєвої позиції як суб'єктів інноваційних прогресивних перетворень в освіті (професійно-рефлексивний компонент).

Реалізація змісту підготовки майбутніх магістрів 3 дошкільної освіти до інноваційної професійної діяльності спрямовується на формування вмінь моделювання і проєктування інноваційної професійної діяльності, упровадження інновацій в освітній процес закладу дошкільної та вищої освіти.

Отже, зміст підготовки майбутніх магістрів 3 дошкільної освіти до інноваційної професійної діяльності доцільно розглядати як систему знань, що сприяють формуванню компонентів готовності до інноваційної діяльності за рахунок інноваційної складової змісту дисциплін професійної підготовки, виробничої практики та інноваційно-спрямованих форм i технологій навчання.

Підготовка майбутніх магістрів проходить у формі проблемного, евристичного, проєктного, контекстного, інтерактивного, змішаного та онлайн навчання 3 використанням «хмарних» технологій, цифрових сервісів і ресурсів (Cogle, Prezi, Canva, Mindmeister, Thinglink, LearningApps, PoowToon, WordArt, Padlet, Piktochart та інші), що охоплює всі етапи інноваційної діяльності та забезпечує таку їі рольову поведінку, яка згодом буде визначальною у майбутній професійній діяльності (Kozlitin, Kochmar, Krystopchuk. \& Kozak, 2020, с. 37-40). Така підготовка будується в логіці формування компонентів готовності: ціннісномотиваційного, інформаційно-когнітивного, діяльнісно-творчого, професійно-рефлексивного до інноваційної діяльності і включає такі етапи: ціле-мотиваційний; інформаційно-пізнавальний; процесуальнотворчий; рефлексивний.

Ціле-мотиваційний етап передбачає створення умов для прийняття магістрантами цілей інноваційної дошкільної освіти як особистісно- 


\section{Інноватика у вихованні. Випуск 13.Том 1. 2021.}

значущих; формування у них стійкої мотивації та ціннісного ставлення до інноваційної діяльності, потреби особистісного і професійного розвитку, готовності до продуктивної взаємодії 3 учасниками освітніх і управлінських процесів; діагностику соціальної й професійної активності, спрямованої на інноваційний розвиток дошкільної та вищої педагогічної освіти.

На цьому етапі навчання здійснюється у формах проблемної лекції та семінару, навчальних тренінгів, відео-конференцій, екскурсій, ознайомлення 3 педагогічними інноваціями, вивчення інноваційних методик і технологій.

Інформаційно-пізнавальний етап передбачає формування у магістрантів цілісного образу інноваційної професійної діяльності шляхом засвоєння знань про сутність, структуру, етапи інноваційної професійної діяльності на конкретній темі навчального матеріалу, ознайомлення 3 етапами інноваційного педагогічного проєктування; оволодіння методологією i методами наукового дослідження для освоєння педагогічних, управлінських новацій, оволодіння власними пізнавальнонавчальними, дослідницькими потребами.

Саме в цей період великого значення набуває активна пошуководослідницька, проєктна діяльность магістрантів, організація продуктивної взаємодії 3 іншими учасниками інноваційного освітнього процесу. Навчання магістрантів здійснюється у формі проблемної лекції, наукового семінару, навчальних проєктів 3 використанням сучасних цифрових технологій.

Процесуально-творчий етап передбачає формування у магістрантів умінь інноваційної професійної діяльності. На цьому етапі основна роль відводиться самостійній практичній роботі науково-дослідницького, проєктувального, експериментального характеру, відбувається розвиток здібностей до науково-дослідницької, інноваційної діяльності, творчого вирішення освітніх завдань у галузі дошкільної освіти та підготовці майбутніх педагогів дошкільного фаху. Практичним результатом етапу $є$ розробка навчального проєкту, який може носити інноваційний пошуковий, методичний або прикладний характер. Апробація проєктів відбувається за допомогою ділової гри, тренінгу, обміну досвідом, під час проходження різних видів виробничої практики.

Рефлексивний етап передбачає розвиток у магістрантів рефлексивних умінь, що дозволяють проводити саморефлексію творчої авторської позиції, аналізувати результати виконання проєктів, оцінювати їх якість та результати власної інноваційної професійної діяльності, визначати напрями діяльності майбутнього магістра на якісно новому рівні.

Організація рефлексивного етапу може здійснюватися у формах семінарів-обговорень, експертної та групової оцінки результатів інноваційної професійної діяльності, консультування, анкетування тощо.

Отже, змістово-процесуальний компонент технології підготовки майбутніх магістрів з дошкільної освіти до інноваційної професійної 


\section{Інноватика у вихованні. Випуск 13.Том 1. 2021.}

діяльності пов'язаний з вибором змісту, форм, методів і технологій навчання магістрантів.

Оцінно-результативний компонент технології розглядається нами як комплекс взаємопов'язаних моніторингових процедур, що здійснюються по завершенню змістово-процесуального компоненту технології з метою визначення ступеня досягнення загальної мети - формування у майбутніх магістрів готовності до інноваційної професійної діяльності в закладах дошкільної освіти та в системі професійної підготовки дошкільних педагогів.

Висновок і перспективи подальших розвідок. Розроблена i впроваджена в освітній процес технологія підготовки майбутніх магістрів 3 дошкільної освіти до інноваційної професійної діяльності відповідає основним вимогам інноваційної педагогічної освіти та формуванню інноваційної особистості педагога. Це досягається завдяки збагаченню інноваційною складовою змісту дисциплін професійної підготовки та виробничої практики, суб'єкт-суб'єктному характеру взаємодії учасників освітнього процесу, спрямованості навчання на формування інноваційного мислення, дослідницьких, проєктувальних, комунікативних, рефлексивних умінь магістрантів, пріоритетності в освітньому процесі проблемного, евристичного, проєктного, контекстного, інтерактивного навчання, сучасних IК технологій.

Проведене дослідження не вичерпує всіх аспектів проблеми підготовки майбутніх магістрів 3 дошкільної освіти до інноваційної професійної діяльності. Перспективним напрямком подальших досліджень може стати розвиток інноваційної компетентності магістранта засобами цифрових технологій, що пов'язано з реаліями і потребами сучасної освіти в Україні.

\section{СПИСОК ВИКОРИСТАНИХ ДЖЕРЕЛ}

Національна стратегія розвитку освіти в Україні на період до 2021 року. Указ Президента України №344/2013. URL: https://zakon.rada.gov.ua/laws/show/344/2013. [Дата звернення 02.05.2021].

Кониепиія розвитку педагогічної освіти (2018). Наказ МОН України № 776 від 16.07.2018. URL : https://mon.gov.ua/ua/npa/pro-zatverdzhennyakoncepciyi-rozvitku-pedagogichnoyi-osviti [Дата звернення 02.05.2021].

Стандарт вищої освіти. Другий (магістерський рівень) вищої освіти. Ступінь «магістр». Галузь знань 01 Освіта/Педагогіка, спеціальність 012 «Дошкільна освіта» (2020). Наказ МОН України від 29.04.2020 p. № 572.

Козак, Л. (2015). Теоретико-методологічні засади підготовки майбутніх викладачів дошкільної педагогіки і психології до інновачійної професійної діяльності. Доктор педагогічних наук. К. 40 с.

Дичківська, I. (2017). Підготовка майбутніх вихователів дошкільних закладів до інноваційної педагогічної діяльності: теорія і методика: монографія. Рівне: Видавець О. Зень, 372 с. 


\section{Інноватика у вихованні. Випуск 13.Том 1. 2021.}

Сисоєва, С. (2003). Педагогічні технології у неперервній професійній освіті. Неперервна професійна освіта: філософія, педагогічні парадигми, прогноз: Монографія. За ред.. В.Г. Кременя. К.: Наукова думка. С. 449-564.

Шапран, О. (2008). Система інноваційної підготовки майбутнього вчителя в умовах навчально-науково-педагогічних комплексів. Доктор педагогічних наук. Нац. пед. ун-т ім. М. П. Драгоманова. К, 2008. 412 с.

Kozlitin Denis, Kochmar Diana, Krystopchuk Tetiana, Kozak Lyudmila (2020). Future Educators' Training for Project Activities Using Digital Technologies. Proceedings of the PhD Symposium at ICT in Education, Research, and Industrial Applications co-located with 16th International Conference "ICT in Education, Research, and Industrial Applications 2020" (ICTERI 2020). c.31-41. ISSN 1613-0073.

\section{REFERENCES}

National strategy for the development of education in Ukraine until 2021 (2013). Ukaz Prezydenta Ukrainy No 344/2013. URL : https://zakon.rada.gov.ua/laws/show/344/2013. [Data zvernennia 02.05.2021]. [in Ukrainian].

The concept of development of pedagogical education (2018). Nakaz MON Ukrainy No 776 vid 16.07.2018. URL: https://mon.gov.ua/ua/npa/prozatverdzhennya-koncepciyi-rozvitku-pedagogichnoyi-osviti. [Data zvernennia 02.05.2021]. [in Ukrainian].

Standard of higher education. The second (master's) leve) of higher education. Master's degree. Field of knowledge 01 Education / Pedagogy, specialty 012 "Preschool education" (2020). Nakaz MON Ukrainy vid 29.04.2020 r. No 572. [in Ukrainian].

Kozak, L. (2015). Theoretical and methodological principles of preparation of future teachers of preschool pedagogy and psychology for innovative professional activity: Doctor pedahohical sciences. K. 40 s. [in Ukrainian].

Dychkivska, I. (2017). Preparation of future educators of preschool institutions for innovative pedagogical activity: theory and methods: monografiia. Rivne: Vydavest O. Zen, 372 s. [in Ukrainian].

Sysoieva, S. (2003). Pedagogical technologies in continuing professional education. Neperervna profesiina osvita: filosofiia, pedahohichni paradygmy, prognoz: Monografiia. Za red. V.H. Kremenya. K.: Naukova dumka. SS. 449564. [in Ukrainian].

Shapran, O. (2008). The system of innovative training of future teachers in the conditions of educational-scientific-pedagogical complexes. Doctor pedahohichnykh nauk. Nats. ped. un-t im. M. P. Dragomanova. K., 2008. 412 s. [in Ukrainian].

Kozlitin Denis, Kochmar Diana, Krystopchuk Tetiana ta Kozak Liudmyla (2020). Future Educators' Training for Project Activities Using Digital Technologies. Proceedings of the PhD Symposium at ICT in Education, Research, and Industrial Applications co-located with 16th International 
Conference "ICT in Education, Research, and Industrial Applications 2020" (ICTERI 2020). cc.31-41. ISSN 1613-0073.

\title{
TECHNOLOGICAL PRINCIPLES OF FUTURE MASTERS' IN PRESCHOOL EDUCATION TRAINING FOR INNOVATIVE PROFESSIONAL ACTIVITY
}

\author{
Liudmyla Kozak \\ Doctor of Sciences (in Pedagogy), Associate Professor, \\ Professor at the Department of Preschool Education \\ Borys Hrinchenko Kyiv University, \\ Kyiv, Ukraine \\ ORCID: 0000-0002-4528-1905 \\ e-mail: l.kozak@kubg.edu.ua
}

\begin{abstract}
The article substantiates the technological principles of future masters' in preschool education training for innovative professional activity. The author's interpretation of the concepts "innovative professional activity of a master in preschool education", "readiness of a master of preschool education to innovative professional activity" were presented; the developed technology of future masters' in preschool education training for innovative professional activity, contained conceptual, semantic-procedural, evaluation-effective components, was presented. The conceptual component reveals the leading idea, purpose, tasks, methodological approaches, principles of future masters' in preschool education training for innovative professional activity. The contentprocedural component covers the stages of preparation of future masters in preschool education for innovative professional activity: goal-motivational, information-cognitive, activity-creative, reflective. The result evaluative component of the technology reflects the procedure for assessing the level of readiness of future masters' in preschool education for innovative professional activity and the result of such training. Formation of future masters' readiness for innovative professional activity occurs in the process of mastering the innovative component of the content of academic disciplines and industrial practice, organization of subject-subject interaction of educational process participants, orientation of training on formation of innovative thinking, research, design, communicative, reflective skills, priorities in the educational process of problem, heuristic, project, contextual, interactive and blended learning, digital technologies, modern forms of organization of the educational process in the higher education establishment.
\end{abstract}

Key words: innovation activity, master's degree in preschool education, readiness for innovative professional activity, innovative pedagogical technology, technology of preparation for innovative professional activity.

Стаття надійшла до редакиії 10.05.2021 p. 